growth of private tutoring. With the emergence of mass private tutoring, distinction between formal and informal learning would get blurred. Private tutoring costs will occupy a significant proportion of household expenditure on education. Efforts to control or monitor private tutoring are likely to meet with only limited success.

Several measures could be taken to cope with the growing incidence of private tutoring. These could include making teachers in the formal school system more accountable and the schools qualitatively more competitive; reviewing the selection criteria for entry to higher education institutions; and, finally, supporting students from poor households and in rural areas so that they are better prepared for entry to reputed and highly competitive higher education institutions.

Since it is not feasible to control supplementary private tutoring and perhaps not even desirable to curb it, considering that it might be raising the country's average levels of achievement, the best option is to adopt a coping strategy that takes care of its negative consequences.

\section{Trends in American Academic Work and Careers}

\section{MARTIN Fin KELSTEIN}

Martin Finkelstein is professor of higher education at Seton Hall University. Address: Seton Hall University, 418 Jubilee Hall, South Orange, NJ 07079, USA. E-mail: finkelma@shu.edu.

Th I994, Jack Schuster and I launched an ambitious project 1 on the future of the American faculty. Retrospectively, we sought to comb the available evidence provided by three decades of national faculty surveys in the United States (mostly in the public domain) to trace empirically the trends in academic work and careers. Prospectively, we sought to place these trends into the context of seismic shifts in the global economy and the mission of higher education and provide an explanation of the dizzying concatenation of trends we were seeing. The fruits of that project were recently published as The American Faculty (Johns Hopkins University Press, 2006).

All in all, the last 30 years have probably seen changes in the American system on a historically unprecedented scale. Since the ig6os, American faculty have grown from a corps of some 300,000 to nearly I.2 million. The sheer magnitude of this growth has been accompanied by a shift in the overall shape and character of the profession.

\section{Institutional and Disciplinary Venues}

The center of gravity of the American academic professions has shifted from the university sector (from about half of the whole in I970 to about 40 percent today) to the two-year community college sector (from about ro percent in 1970 to 20 percent today) and the public four-year college sector. Moreover, the center of gravity has also shifted from the traditional arts and science fields to the professions. Indeed, the majority of newly hired faculty in the past decade are in the professions.

\section{Demography}

The proportion of women in the academic professions has

The center of gravity of the American academic professions has shifted from the university sector (from about half of the whole in 1970 to about 40 percent today) to the two-year community college sector (from about 10 percent in 1970 to 20 percent today) and the public four-year college sector.

increased overall from about I7 to 35 percent since 1970 . However, if one examines new entrants to the academic professions over the past decade, one finds that about 45 percent are women; and in some fields in the humanities and social sciences as well as some professions such as education, the majority of newly entering faculty are female. At the same time there have been notable, albeit less dramatic, increases in the representation of foreign-born faculty (especially Asians and especially in the natural sciences and engineering) and faculty from racial and ethnic minority groups (Asian, Black, and Hispanic).

\section{New Types of Appointments}

While about 45 percent of current college teachers in the United States are employed part time, over the past decade and largely under the radar screen of most observers colleges and universities in the United States have been engaged as well in the restructuring of full-time faculty appointments. Nominally, that restructuring has involved the introduction of a parallel system of fixed-term contracts alongside the traditional tenure system for full-time faculty.

This parallel system of full-time, fixed-term contracts has grown rapidly. Since I993, the majority of new full-time faculty hired in US higher education institutions have been appointed off the tenure track. This new type of full-time appointment differs not only (or even primarily) from traditional tenure appointments in contract duration but also in function. These appointments involve more specialized roles that differ from the Humboldtian model of a single individual playing a functionally integrated (teaching, research, and service) role-thus supporting a largely tacit, unexamined depar- 
ture from the traditional faculty role in the United States. They typically focus their energies on only one of the three traditionally integrated faculty functions (teaching or research or service) and spend less time overall on their more circumscribed institutional responsibilities

For the largest group of full-time, fixed-contract (teachingonly) faculty there is little involvement in research and institutional governance and for research-only faculty little involvement with teaching and students. In a sense, full-time, fixedcontract appointments of the teaching-only variety represent a kind of aggregation of multiple part-time appointments into one and a significant departure from what has historically been one of the distinctive sources of American higher education's strength. Overall, fixed-term-contract faculty spend as much as Io to 20 percent less time on their work as tenured/tenuretrack faculty (and that difference is accentuated at research universities), more time than "generalist" colleagues on teaching, and less time on research (if teaching is their principal activity); publish much less; and are less engaged in student contact. They are also less involved in institutional service and administration.

It is important to note that although these appointment differences are discernible across institutional types and academic fields, they do take on different guises by institutional type and disciplinary venue. Teaching-only appointments are increasingly common at research universities, especially in the humanities (English, foreign languages, mathematics) and in several of the professions (business, nursing, other health sciences). Administrator and program-director appointments are especially common in public two-year institutions.

\section{The Changing Academic Career}

Over the past half century, a singular, predictable, lockstep academic career track developed in the four-year collegiate sector in the United States as follows: (a) PhD receipt; (b) initial appointment to full-time, tenure-ladder-rank position (assistant professor); (c) review for tenure after a six-to-seven-year probationary period; (d) tenure review based on success in a trinity of teaching, research/publication, and service (institutional and external); and (e) promotion to associate and full professorships.

Newly available evidence from the US Department of Education's National Study of Postsecondary Faculty suggests that this modal, homogeneous pattern is fast becoming a thing of the past. For part-time faculty, the vast majority of previous work experience is also part time, and for full-time faculty, primarily full time. Indeed, among those who held full-time appointments in 1998, 8 out of ro had always worked exclusively on a full-time basis.

When we compared the work experience of fixed-term-contract appointees with tenured/tenure-track appointees, a similar, if less pronounced, pattern emerged. Current tenured/tenure-track faculty usually start out that way-about three-fifths had reported only previous tenured/tenure-track experience. At the same time, two-thirds of current fixed-termcontract faculty typically pursued their careers entirely in fixedterm-contract positions. While there is some permeability between fixed-term-contract and regular tenureable full-time appointments (about one-fourth move from fixed term to tenure track), the two have come to constitute quite independent career tracks for the majority of American faculty.

\section{Quo VADIS?}

How shifts in the American academic profession will impact the long-term health of the higher education enterprise is open to debate (although those closest to the profession seem the least sanguine). Clearly these changes represent one form of a larger global restructuring of academic work that the world will be wrestling with for some time to come.

\section{Can Hong Kong Keep Its Lead in the Brain Race? \\ Philip G. Altbach and Gerard Postiglione}

Philip G. Altbach is Monan professor of higher education and director of the Center for International Higher Education at Boston College. Gerard Postiglione is professor in the Faculty of Education at the University of Hong Kong. Address: Faculty of Education, University of Hong Kong, Pokfulam Rd., Hong Kong, China.

T ong Kong's future depends on its human resources-the - 1 skills of its people in such fields as financial management, law, science and technology, tourism, the management of trade and business, and related fields. In a recent poll of II,000 business leaders, almost 20 percent highlighted an inadequately educated work force, as the most problematic factor for doing business in Hong Kong. In the World Economic Forum's Global Competitiveness Report of 2005/06, Hong Kong dropped 7 places to 28 out of II7. To build and maintain human capital, Hong Kong needs world-class innovative and competitive universities. Singapore, similar to Hong Kong in its dependence on brains and innovation, has been rapidly internationalizing its higher education system, actively recruiting scholars and students globally and from mainland China as well. Singapore (like South Korea and Taiwan) got a big jump on Hong Kong by heavy investment in science and technology R\&D in the I980s and I990s. Hong Kong has paid for that mistake and still lags behind with a GDP expenditure on R\&D of 0.7 percent compared to I.9 percent on average in the 